\title{
The Evaluation of Space Quality in Outdoor Open Spaces: Bursa Historical Bazaar and Khans District as a Case
}

\author{
Seyhan Sen ${ }^{1}$ Tulin Vural Arslan ${ }^{2}$
}

\begin{abstract}
The evolution of urban life, resulting from the developments in technology, economics and social life, along side with rapid urbanisation has shaped functions and structures of urban outdoor spaces. Together with this change, the expectation of quality has also changed which necessitates the new definitions and parametres about the concept of quality of life. Because the concept of quality consists of various components, the promotion of these definitions and parameters requires taking the specific qualifications of the particular space into consideration. In this study, quality of life and space in Bursa Historical Bazaar and Khans District is evaluated in regard to parameters which are identified in the content of study. These parametres are developed both by the examination of related literature about the space quality and also surveys about the users' expectations from the site. In in order to identify the users' expectations from the site, a survey was conducted of 400 people in 4 well-known Khans in the district. The questionnaire items were factor analyzed to explore the principal components of outdoor space quality from the viewpoint of users.
\end{abstract}

\section{Introduction}

The emergence of capital accumulation resulting from technological and industrial developments has increased people's material income, and has led to the emergence of a quantitative and qualitative diversification that goes beyond the mere meeting of basic needs. As a result of this, the lifestyles of societies have changed. These developments have shown that economic indicators will no longer be the sole determinant of society's level of welfare. Due to these changes, social surveys that use a number of analytical methods have been developed for examining and following social change (Sirgy et al., 2006). By means of the researches carried out in this way, a quality of life concept has appeared.

Besides this, the increase in universal problems such as the deterioration in environmental conditions like the exhaustion of natural resources, physical and social dilapidation, inequality in access to basic services like health and education and in distribution of welfare, have resulted in the appearance of the life quality concept (van Kamp et al., 2003). According to the World Health Organisation (WHO), the perception and evaluation formed by an individual, according to his position in life, from the context of social, cultural and physical environment defines his quality of life (The WHOQOL Group, 1993).

One of the important components of the life quality concept, which attempts to reach a certain standard in different areas such as health, education and physical environment, is 
that of space quality. In order to target public space quality, it is necessary to develop an approach and methods by which both the objective components of a "quality" environment and the subjective assessments of the users of this space may be discussed (Erkut, 1995).

The main aim of this study is to research the quality factors of urban spaces, which take on the task of cohesiveness in every city, with regard to making them more usable and liveable. Other aims of the study are to pioneer other researchers who will do work in this field by proposing a model for space quality and to be a reference for them by obtaining data.

The scope of the study will be limited to an analysis of the courtyards of the Pirinç Han, Koza Han, Fidan Han and Emir Han, which are inn-yards forming examples of the urban space of the Bursa Khans District that still continues the urban activity it has carried out historically and which is important for its historical features, in the context of their urban space quality, and, by means of an evaluation of these spaces with regard to the opinions of their users, to a research into what quality inputs may be made in order to ensure space quality.

As a research method, use has been made of a definition of space and urban space concepts, an explanation of human-environment interactions, a determination of people's basic necessities, and a literature research into obtaining space quality indicators and defining the study field. When establishing criteria for space quality, it is necessary to consult the user's subjective assessment. For this reason, the most suitable method for field study, the questionnaire technique, was applied. The questions asked to the users aimed at their spatial evaluations were transferred to a statistical analysis program and the factor analysis method was used in the evaluation process. When the study was begun, one of the problems encountered was the absence of a clear definition of the concept of urban space quality in the literature and the fact that few studies had been carried out on this subject. Therefore, when defining the parameters for urban space quality, a new method was developed.

\section{The Concept of Space Quality}

Quality of space is dependent on the type of activities to be carried out in an area and on the features of environmental factors. Since they are at the service of all sectors of the populace, urban spaces possess a wide variety of user profiles having different statuses and many different needs. This situation gives rise to differentiation in the activities to be carried out in urban spaces (Atabek, 2002).

The main quality components of urban open spaces proposed by the Council of Europe are as follows:

- The place should be in use and give the message that it is available for use

- It should possess aesthetic appeal

- It should be safe

- It should be affordable

- It should offer natural surroundings, such as green spaces

- A high rate of transfer between internal and external spaces should be provided

- It should be equipped with activities that have a high probability of being carried out and which 
will meet the most necessary requirements

- It should be accessible to and usable by children, the elderly and the disabled

- Materials should be chosen that are suitable to requirements and differentiation in usage should be emphasised by exchange of materials

- Comfortable surroundings should be offered against natural environmental effects like the sun and wind

- Besides being suitable for the needs of groups who are most likely to use the place, it should also offer variety

- The place should be a visual work of art and should also provide a social environment (İnceoğlu et al., 1995).

- In another study, however, the factors used in the evaluation of urban spaces with regard to quality are listed as follows:

1. Liveability

2. Suitability of function

3. Legibility

4. Provision of visual satisfaction

5. Assignment of meaning by association

6. Balance between spaces that are under private and public scrutiny

7. Manageability (Atabek, 2002).

Lynch (1960) states that for a good urban structure, five conditions, namely vitality, soul, conformity, access and control, should be present in the city.

Van der Voordt (2005) has grouped the quality components in architecture under four headings, which are technical quality, functional quality, aesthetic quality and economic quality:

1. Technical quality: a physical quality that identifies to what extent the requirements related with the instrumental and technical problems needed for a structure or space have been met. It shows by how much the conditions in a building or space such as safety, health, climate, temperature, humidity, illumination, natural light and acoustics have been provided.

2. Functional quality: this is related with how suitable a structure or space is for the activities which should be found within, with regard to its usability.

3. Aesthetic quality: this is related with how a structure or space is perceived or experienced in terms of how beautiful, pleasant, encouraging, and satisfying it is.

4. Economic quality: related with how effectively financial resources are used, this depends on how much income a building or space generates (İnceoğlu, 2007).

Along with the quality concept, the space quality concept is also one that needs to be examined in a multidimensional and detailed way. Numerous studies can be found related with this. When all these studies are examined, it can be seen that one single classification has not been made with regard to space quality indicators. It is therefore essential within the scope of this study to create space quality indicators. In this context, it may be said that the classification made by Van der Voordt (2005) comprises the basic spatial quality parameters in the most general sense. Yet one of Van der Voordt's (2005) main quality factors, the economic quality factor, has been left out of this study, due to 
the fact that urban spaces are not in a position to generate income in an economic sense. In order to create the sub-indicators of these main quality factors, it is necessary to have a look at the needs served by quality.

In this context, Gür (1996) classified psycho-social and cultural concepts under Maslow's (1943) human needs. Accordingly, she examined:

1. For physiological (biological) needs; the concepts of shelter, comfort, continuing the bloodline, continuity, durability, and contextualism,

2. For safety needs; the concepts of safety of life and property, privacy, preventing the feeling of overcrowding, determining area of sovereignty, defence, ease of orientation, and direction-finding,

3. For the desire for belongingness (bonding) needs; the concepts of socio-cultural acceptance, joining human organisations, socialisation, establishing social interaction, using communal areas, identifying with the place, contributing to the collective memory, and protecting symbolic values,

4. For prestige needs; the concepts of identity/self-respect, privilege, appropriation, individual or group status symbols, imageability, distinguishing signals, and perceptibility,

5. For self-actualisation (developing skills) needs; the concepts of assignment to social groups, participation, freedom of choice, production, flexibility, improvability, dynamism, and incompleteness,

6. For intellectual, emotional and aesthetic fulfilment needs; the concepts of diversification of formal aesthetic ideas, complexity, sensitivity to energy and life, sensitivity to problems of the future, inclination towards future problems, consolidation of social awareness, aid to humans and to mankind (Gür, 1996).

\section{Case Study: A Space Quality Evaluation of Bursa Khans District}

Bursa, due to its geographical location and its fertile soils, has hosted various civilisations for centuries. It is known that the earliest settlements date from the 7th century BC. After the Roman and Byzantine periods, the city of Bursa was declared as the first capital of the Ottoman Empire, a feature for which it has special importance (Özendes, 1999). The city, with several potentials such as sericulture, trade routes, trade organisations and the presence of foreign tradesmen, became a commercial and manufacturing centre (Köprülü Bağbanc1, 2007). 


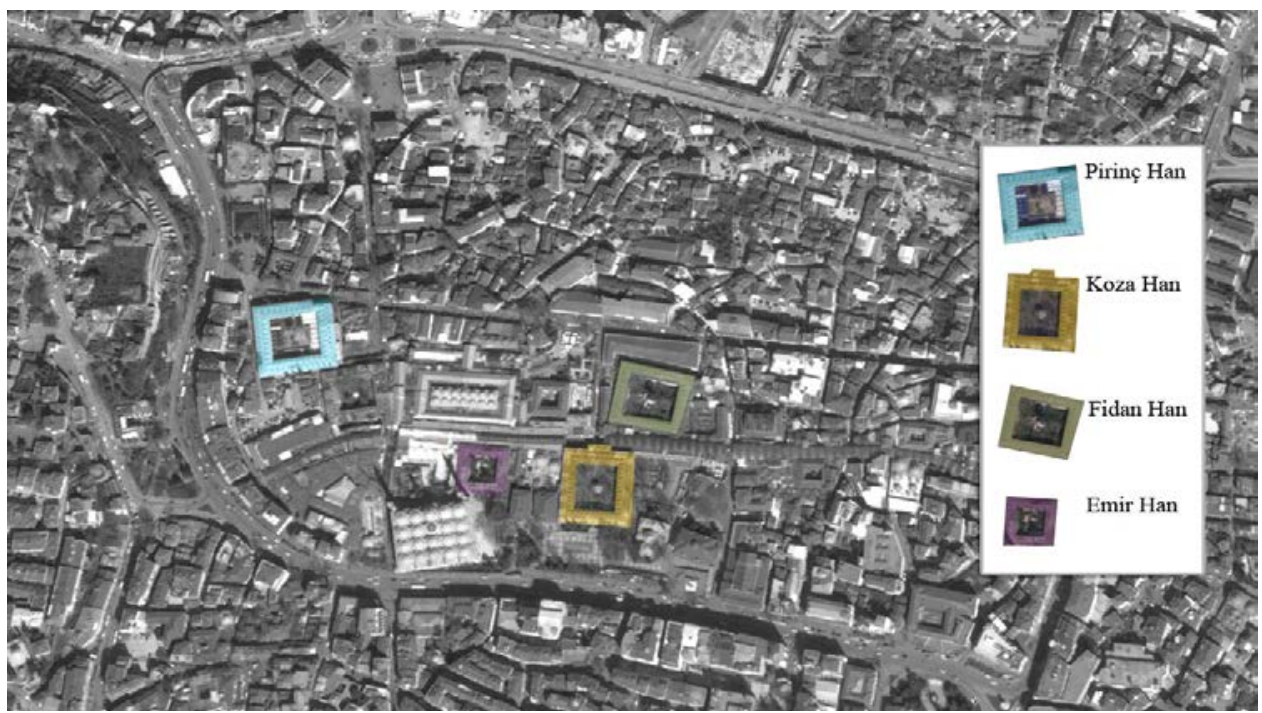

Fig. 1. Khans examined within the scope of the study (Google Earth)

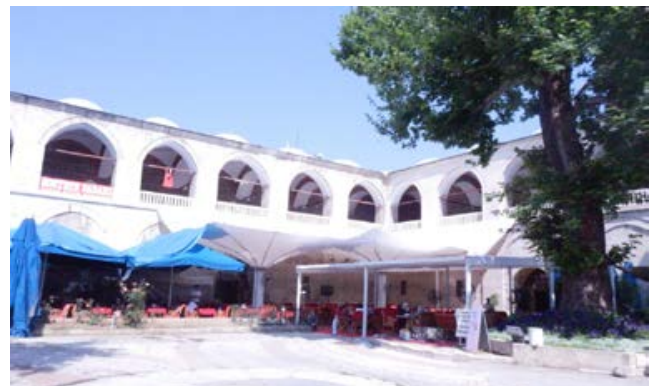

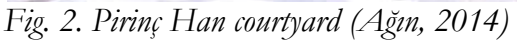

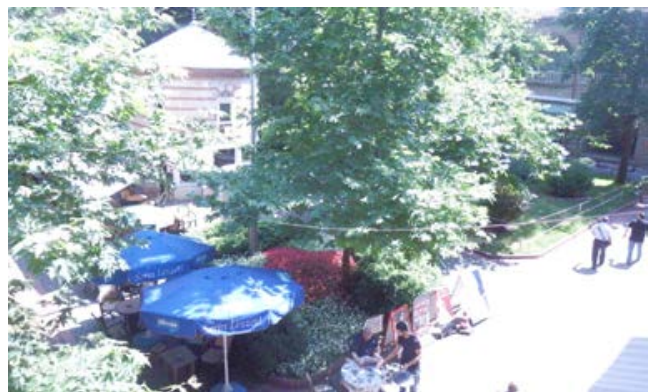

Fig. 4. Fidan Han courtyard (Ă̈ın, 2014)

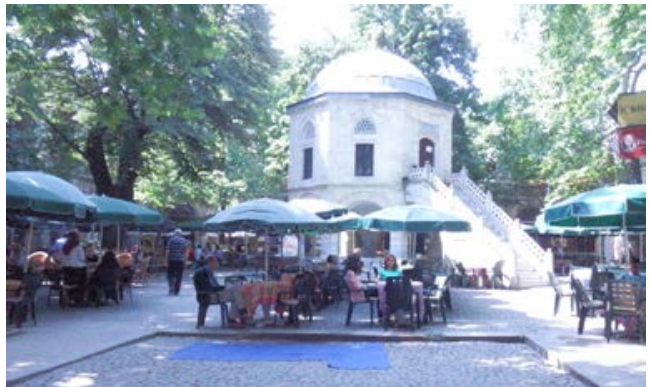

Fig. 3. Koza Han courtyard (Ă̈ın, 2014)

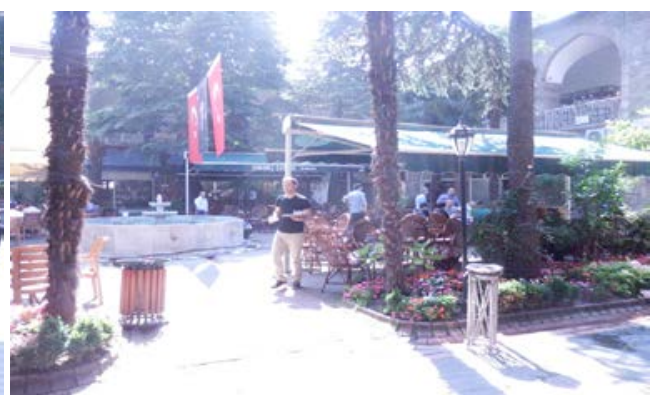

Fig. 5. Emir Han courtyard (Ağgn, 2014)

The importance of the study area stems from the historical value it contains and the fact that it is still the only centre of the city. The Historic Bazaar and Khans District is located approximately in an area bounded by Cemal Nadir Street on the west side, Gökdere Stream on the east side, Haşim İşcan Street to the north and Atatürk Street to the south. 
In the Historic Bazaar and Khans District, which developed with a clear system dependent on manufacture and commerce, trade was carried out in shops, markets, Ottoman bazaars, covered bazaars and khans. One of these trade setups which performed distinct functions and which had spatial relationships with each other, the khans, is the research subject of this study.

\section{Method}

Some khans were set aside for the collection and distribution of one particular commodity, and in time these began to be referred to by the name of that commodity. In the Bursa Khans District, khans such as the Rice Khan, Silk Khan and Salt Khan were named in this sense, according to the name of the function they performed (Doğru, 1995).

In the study, the Pirinç Han (Rice Khan), Koza Han (Cocoon Khan), Fidan Han (Sapling Khan) and Emir Han (Emir Khan) are discussed in detail and the locations of these khans are shown in Fig. 1,2,3,4,5.

When establishing the criteria for space quality, it is necessary to consult the user's subjective evaluation. For this reason, the questionnaire technique, which is the most suitable method in field study, was applied. By providing the facility of observing the reactions given to the questions asked through face-to-face interviews, the questionnaire technique has contributed to the research at the stage of interpretation of the obtained data.

When commencing the study, one of the problems encountered was the absence of a clear definition of the concept of urban space quality in the literature and the fact that few studies had been carried out on this subject. Therefore, when defining the parameters for urban space quality, a new method had to be developed, and the following procedure was observed:

In the study, quality was defined by the extent to which human needs were met. For this reason, first of all Maslow's (1943) hierarchy of human needs was used as a starting point. In order to find the spatial equivalents of these basic needs, a literature study was carried out. In this context, the spatial quality factors corresponding to basic human needs that were developed in Gür's (1996) study were used as a base. Then, the equivalent concepts defined by Gür in her 1996 study were interpreted together with the main quality factors defined by Van der Voordt (2005). It is clear that all these spatial quality factors will show differentiation according to the different qualities of the space, depending on whether it is an indoor or an outdoor space. Therefore, in this context, these concepts were re-examined within the scope of the study specific to urban space and a new index of parameters was created (Table 1).

\section{Questionnaire Study}

In the context of urban space quality evaluation, as part of the aim and scope of the study, the questionnaire study was carried out among 400 people in four different khans of Bursa's Historic Bazaar and Khans District. In the Pirinç Han, Koza Han, Fidan Han and Emir Han, 100 people participated for each khan. While determining 
these khans to be studied, in order to be able to obtain reliable data, care was taken to show that the khans had different features from each other and that they were widelyused places. With regard to the activities that take place in their courtyards, the Pirinç Han is regarded as a place where young people meet, the Koza Han is intended for tourists, the Fidan Han is intended for relaxation, and the Emir Han tends to be used by tradesmen. The questions in the survey were not directed towards the obligatory users of the khan, the khan tradesmen, but towards those who prefer to use the khan, that is those who come and visit it.

The survey questions were prepared with the aim of measuring how the users of the spaces perceived them. The questionnaire study is made up of two sections. The first 13 questions, found in the first part, which is the section that evaluates the demographic structure and utilisation, are aimed at demographic information such as gender, marital status, and education level, plus utilisation information like frequency of visits to the courtyard and time spent in the courtyard. The questions appearing in the second part, which is the section in which quality criteria are determined and evaluated, were prepared by taking the spatial quality parameters into consideration and were directed towards determining the users' feelings and opinions regarding space quality by using a five-point Likert scale for the statistical evaluation of these. The question paper was prepared in such a way as to keep the face-to-face meeting period to a minimum. The survey questions were composed in language that the users could easily understand.

The analyses were completed by transferring the users' responses to the survey questions to the IBM SPSS Statistics 22 program. During this evaluation process, frequency and factor analysis methods were applied and the relevant graphs were drawn up. When evaluating the study data, frequency distribution was given for the categorical variables, while for the continuous variables, descriptive statistics were given. 
Table 1. Structural formation of suggested urban space quality parameters (adapted from Van der Voordt (2005), Maslow (1943), and Gür (1996)

Quality factor Human needs

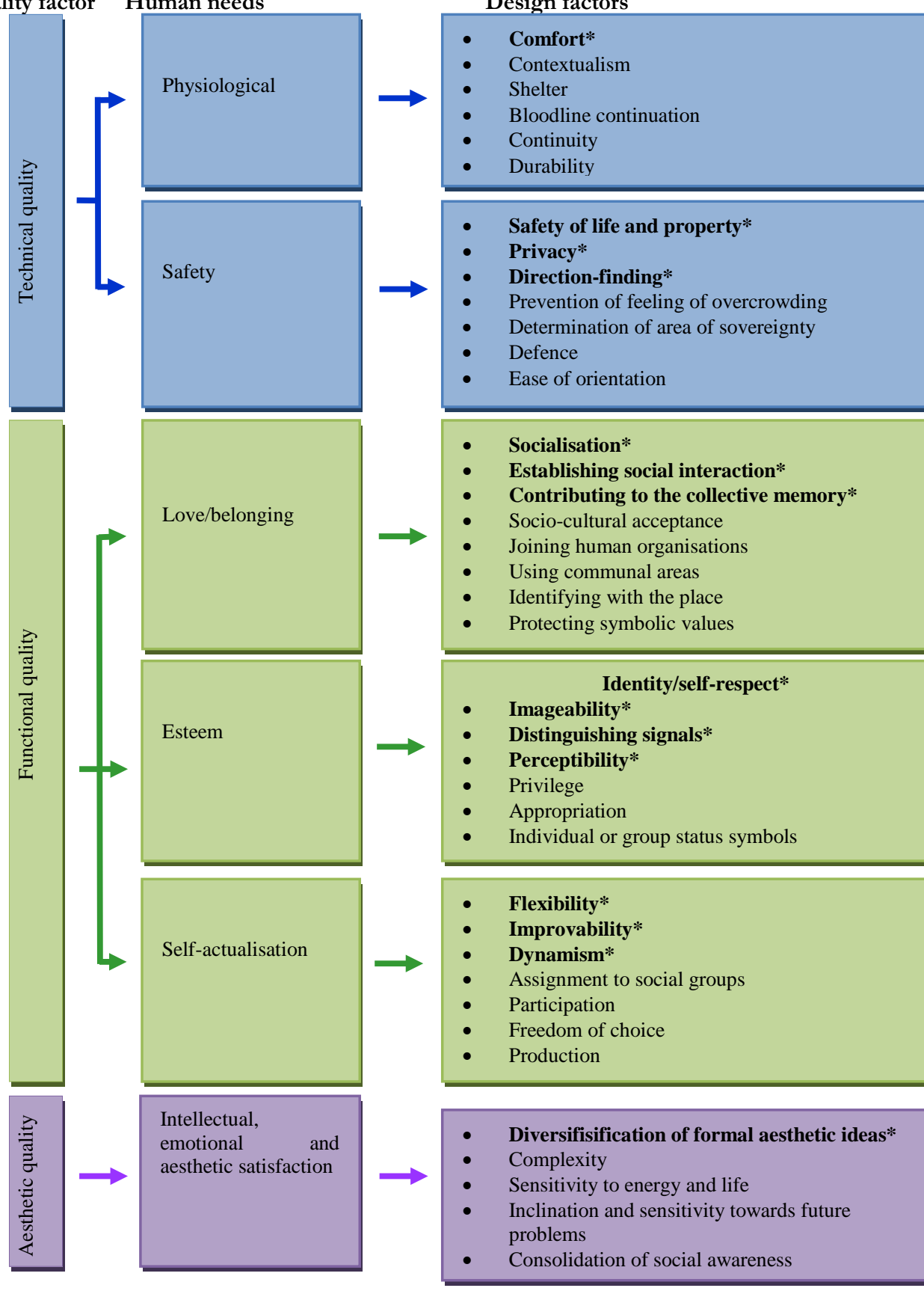

* These concepts were evaluated as the suggested urban space quality parameters within the scope of the study.

In the evaluation of the questionnaire study related with quality of urban spaces, demographic questions such as gender, marital status and educational level were assessed, and diagrams and graphs were prepared. 
Table 2. Urban space quality parameters obtained within the scope of the study

\section{Van der \\ Voordt's quality factors \\ Maslow's human needs}
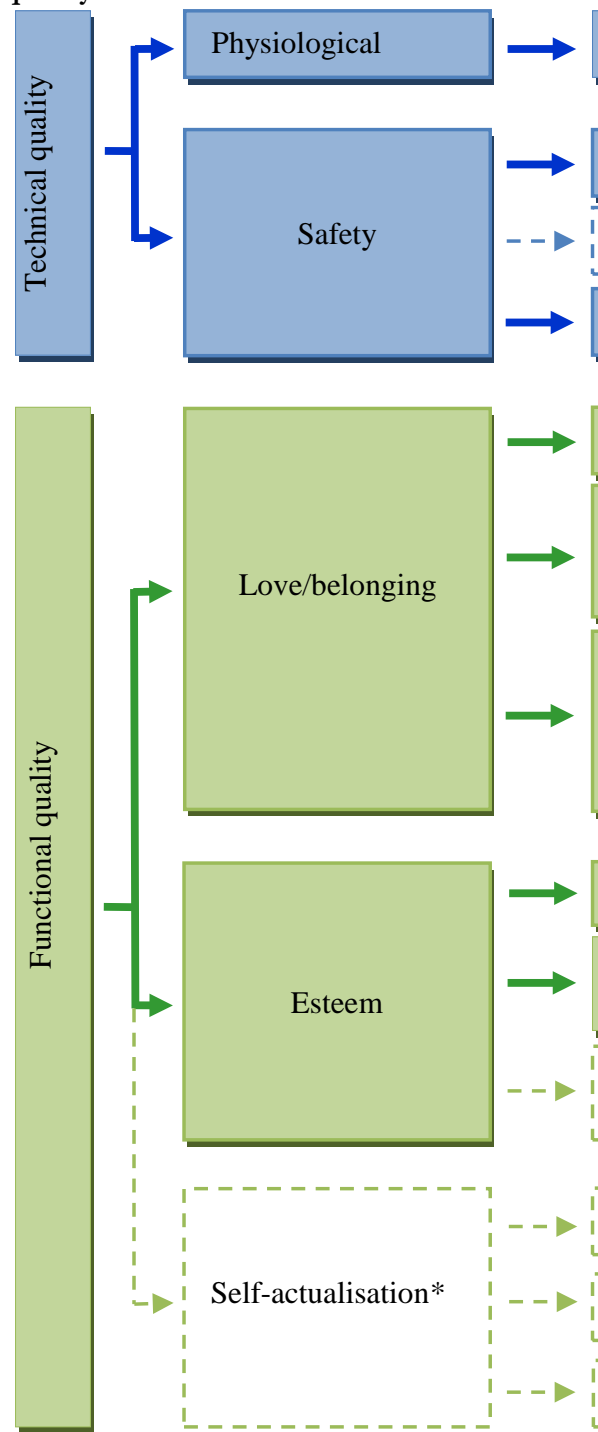

\section{Flexibility*}

$-1$

Improvability*

- - - - - - - - = -

Dynamism*
Suggested space quality Urban space parameters (adapted from quality parameters Gür)

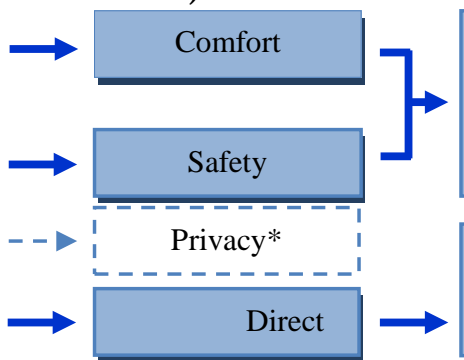

Directionfinding/accessib le services

Comfort-safety obtained

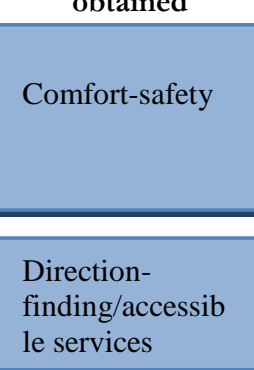

Establishing social interactionsocialisation

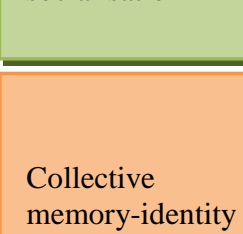

Inageability

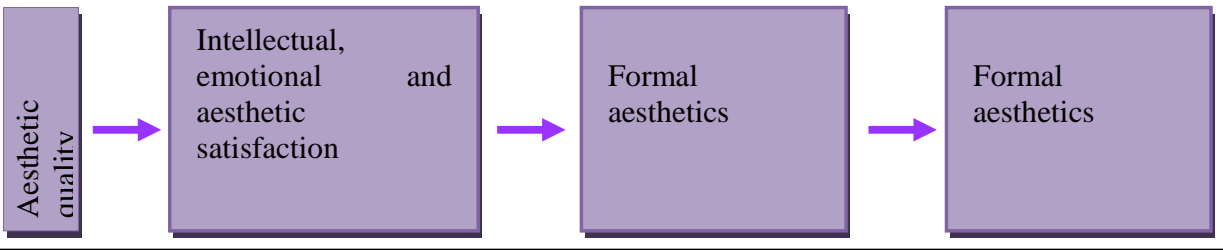

* These concepts are not included within the urban space parameters obtained from the factor analysis made as a result of the field study. 
For the evaluation scale related with quality of urban spaces, factor analysis was carried out and initially, from the 14 parameters, as part of the reliability scale, 6 sub-dimensions were evaluated (Table 2). Reliability analysis was applied to the sub-dimensions and as these were found to be reliable, the study was begun. To determine whether there was a difference between two independent groups, Independent Samples t-test was applied, whilst One-Way Analysis of Variance was applied to determine whether there was a difference among more than two independent groups.

\section{Findings}

In the study, quality parameters applicable to all urban spaces have been determined by making use of Maslow's (1943) and Gür's (1996) studies. These quality parameters were tested by consulting the views of users of 4 khans possessing different features in the Bursa Khans District, and as a result of this it was revealed that for this area 6 basic factors came to the fore, containing the parameters of "collective memoryidentity", "comfort-safety", "formal aesthetics", "direction-finding-accessible services", "imageability", and "establishing social interaction and socialisation", in order of importance. Starting from this point, it is seen that these 6 factors will need to be emphasised in any future work and improvements to be done in this area. Therefore, it can be seen that knowledge of users' expectations is essential with regard to creating a better quality environment. In this study, the idea is suggested that if work is carried out in the matter of ensuring the improvement and continuity of these 6 factors, spatial quality will improve further.

As a result of the factor analysis made, the fact that among the needs suggested as part of the khans examined as urban space examples in the Bursa Khans District, the "privacy" and "distinguishing signals" parameters, and the "self-actualisation need" containing the "flexibility", "improvability" and "dynamism" parameters did not appear, is a striking finding. The characteristic of urban spaces by which human relations increase by ensuring socialisation through bringing people together comes to the fore. The fact that the need for privacy did not appear among the parameters suggested for the users in this study tends to prove that urban spaces have this feature. In other words, it is revealed that in urban spaces, rather than wishing for privacy, which means that a person wishes to withdraw himself physically and psychologically from society, people come to these places because they are urban areas that ensure they can meet other people and socialise with them. Furthermore, it can be seen from these results that these places are not intended to be distinctive, flexible, improvable or dynamic places by the users of these courtyards. From this aspect, within the scope of the study, this coincides with the fact that the most important need the users expected to be met was found to be the collective memory-identity parameter. Stemming from the historic quality of the study area, it can be seen that these places, rather than being desired as changeable, flexible, dynamic spaces, are wished to be unchanging places that belong to the collective memory and identity.

When the factor analysis results of all these khans are examined, the fact that among these factors, the "collective memory-identity" parameter appears as the most important factor for the khans in general, shows that the historic feature of these places is very 
important for people and that especially these urban spaces are preferred for this reason. Therefore, when renovations are made by local authorities in these places, it is seen that it is essential that their historic features be preserved, that designs should not be made which lead to these places losing their identity, and that action in this matter should be taken in a more careful and conscientious way. In this context, when local authorities renew places like these, they should cooperate with the necessary departments of universities and should conduct serious research by consulting the views of users on this subject. For, just as it is unthinkable that places have no users, so it is clear that places where users' opinions and needs are ignored will not be able to continue their existence. In this sense, with a view to creating more usable and liveable spaces, it is necessary to determine correctly the relationship between users' needs by establishing quality criteria.

\section{Conclusion}

It can be seen in this study that it is not possible to apply all the quality parameters everywhere in the same way and in the same order. In this context, it is obvious that if these analyses had been made in a shopping centre or a school building, different results would have appeared. Therefore, it is revealed in this study that in order to improve the definition and parameters related with space quality, it is necessary to take into account the specific features of each space.

With this study, a way has been paved for future studies to be made in this area by presenting both a suggested model and a suggested method with these parameters. This study reveals that in order to determine the quality of spaces, not only the physical features of the space, but also, together with these, the subjective assessments of its users need to be dealt with.

\section{References}

Ağın, S. (2014). Bursa Taribi Çarşı ve Hanlar Bölgesi fotoğraf arșivi. Bursa.

Atabek, E. (2002). Kamusal mekânlarda kalite: Yuldı Teknik Üniversitesi kampüsünde kullanuc görüslerine dayalı kalite değerlendirmesi. Yüksek lisans tezi, İTÜ Fen Bilimleri Enstitüsü, İstanbul.

Doğru, H. (1995). XVIII. yürynla kadar Osmanl kentlerinin sosyal ve ekonomik görüntüsü. Eskişehir: Anadolu Üniversitesi.

Erkut, G. (1995). Kentsel mekân ve yașam kalitesi. Mimari ve Kentsel Çevrede Kalite Arayısları Sempozyumu'nda sunulan bildiri. İTÜ Mimarlık Fakültesi, İstanbul, 5-7 Haziran.

Gür, Ş. Ö. (1996). Mekân örgütlenmesi. Trabzon: Gür.

İnceoğlu, M. (2007). Kentsel açı mekanlarn kalite açısindan değerlendirmesine yönelik bir yaklaşım: Istanbul meydanlarmin incelenmesi. Doktora tezi, YTÜ Fen Bilimleri Enstitüsü, İstanbul.

İnceoğlu, M., Ulusu, T. and Paker, G. (1995). Ders notlar. İstanbul: İTÜ.

van Kamp, I., Leidelmeijer, K., Marsmana, G. and Hollander, A. (2003). Environmental quality and human well-being towards a conceptual framework and demarcation of concepts; a literature study. Landscape and Urban Planning, 65.

Köprülü Bağbanc1, Ö. (2007). Bursa Hanlar Bölgesi değișim ve dönüşüm sürecinin incelenmesi üzerine bir araștırma. Doktora tezi, YTÜ Fen Bilimleri Enstitüsü, İstanbul.

Lynch, K. (1960). The image of the city. Cambridge: MIT.

Maslow, A. (1943). A theory of human motivation. Psychological Review, 50.

Özendes, E. (1999). Osmanli'nn ilk baskeenti Bursa. İstanbul: Yap1 Endüstri Merkezi

Sirgy, M.J., Michalos, A.C., Ferriss, A.I., Esterlin, R., Patrick, D. and Pavot, W. (2006). The quality of life research movement: past, present and future. Social Indicators Research, 76. 
Voordt, D.J.M. van der. (2005). Architecture in use: an introduction to the programming, design and evaluation of buildings. Amsterdam: Architectural Press.

The WHOQoL Group (1993). Study protocol for the world health organization project to develop a quality of life assessment instrument (WHOQOL). Quality of Life Research, 2. 